\title{
Could Epigenetics Play a Role in the Developmental Origins of Health and Disease?
}

\author{
WAYNE S. CUTFIELD, PAUL L. HOFMAN, MURRAY MITCHELL, AND IAN M. MORISON \\ Liggins Institute and the National Research Centre for Growth and Development [W.S.C., P.L.H., M.M.], University of Auckland, \\ Auckland 1001, New Zealand; Department of Biochemistry [I.M.M.], University of Otago, Dunedin 9054, New Zealand
}

\begin{abstract}
Following Barker's observations of an association between birth size and later adult diseases, considerable efforts have been made to define the characteristics of low birth weight groups in childhood. In this review, the phenotypic and biochemical characteristics during childhood of three low birth weight groups are summarized: children born following inviter fertilization (IVF), small for gestational age (SGA), or very premature. Each of these groups is likely to have been exposed to an adverse environment at different developmental stages. The triggers and mechanisms leading to programmed changes in growth, development, and metabolism of these groups of children have yet to be identified. Epigenetics has been proposed as a potential mechanism for these programmed changes through environmentally induced changes in gene expression. Data from animal models in which environmental, particularly nutritional, manipulation leads to changes in DNA methylation are presented. The relevance of these animal studies to IVF, SGA, and very premature children are discussed as are potential candidate genes that may have undergone epigenetic modification to alter growth and metabolism. (Pediatr Res 61: 68R-75R, 2007)
\end{abstract}

$\mathrm{O}$ ver the past $30 \mathrm{y}$, pediatricians have focused on cognitive function, growth failure, and short stature as the principal health care issues facing children born SGA. In the early 1990s, Barker proposed the fetal origins hypothesis of adult disease, a simple but fundamental hypothesis in which the origins of diseases in adults begin in utero (1). Barker and colleagues' observations extended to the range of diseases associated with low birth weight: atherosclerosis, coronary heart disease, type 2 diabetes mellitus, syndrome X, stroke, and chronic bronchitis ( 2-4). These observations have been corroborated by other epidemiologic studies, including those performed in Europe and the United States (5-7).

The interest in this field has grown rapidly over the past decade. There have been in excess of 1000 publications in the field of the developmental origins of adult disease and an incorporated international society was established that exclusively focuses on this field of research - the Society for the Developmental Origins of Health and Disease. However, the most critical questions in this field remain unanswered. Firstly,

Received December 1, 2006; accepted January 22, 2007.

Correspondence: Wayne S. Cutfield, M.D., University of Auckland, Department of Pediatrics, Faculty of Medicine and Health Science, Private Bag 92019, Auckland, 92019, New Zealand; e-mail: w.cutfield@ auckland.ac.nz

Funding support for this work from the National Research Centre for Growth and Development and Health Research Council of New Zealand.

DOI: $10.1203 /$ pdr.0b013e318045764c which of the children who have biochemical markers of metabolic disease will go on and develop overt metabolic disease in adult life? Secondly, what are the initiating events that trigger persistent metabolic programming. Thirdly, what are the mechanisms that lead to adverse programmed metabolic changes? It is this latter question that is the focus of this review.

The low birth weight group includes those born SGA, premature, or following IVF, which is often associated with both SGA and prematurity. These three common childhood groups are likely to have been exposed to an adverse environment during different phases of early development: periconception for IVF, the last trimester of pregnancy for SGA, and the neonatal period for those born prematurely. This review will first characterize the auxological and metabolic differences of these three groups compared with normal children, then describe the epigenetic mechanisms by which these characteristics may have occurred, and finally outline gene candidates potentially involved in these phenotypic alterations. Although there is currently no published evidence linking epigenetic modification to programmed change in growth and metabolism in humans, the data from animal models and their potential relevance to these three groups will be discussed.

\section{CHILDHOOD CLINICAL CHARACTERISTICS}

SGA children. SGA children have an increased risk of short stature. Although approximately $80 \%$ of SGA children achieve a height within the normal range by 6 mo of age $(8,9)$, short adult stature occurs in $5.2 \%$ of those with low birth weight and $7.1 \%$ of those with low birth length $(8,10)$. As a group, SGA children fall about $4 \mathrm{~cm}$ short of their genetic height potential (11). Conflicting reports of abnormalities in the growth hormone-IGF-I axis of short SGA children have been published. Although reduced spontaneous growth hormone secretion has been found, this effect is likely to be minimal if corrected for age (12). Low serum IGF-I and IGFBP-3 levels have been observed but when SGA children are matched for height and body mass, these values are slightly elevated and correlated with fasting insulin levels (13). Diminished IGF-I response to growth hormone (14) suggests a partial defect in the GH receptor or postreceptor

\footnotetext{
Abbreviations: AS, Angelman's syndrome; BWS, Beckwith-Wiedemann syndrome; CpG, cytosine phosphate guanine; DMR, differentially methylated region; IVF, in vitro fertilization; PCOS, polycystic ovarian syndrome; SGA, small for gestational age
} 
pathways. Collectively, these changes are likely to be subtle and do not adequately explain the poor growth many of these children suffer during childhood.

The endocrine and metabolic changes with SGA include reduced insulin sensitivity, lipid alterations, premature adrenarche, and polycystic ovarian syndrome. Almost all other metabolic abnormalities can be attributed to reduced insulin sensitivity and the development of insulin resistance with increasing age and obesity. The long-term consequences of insulin resistance include type 2 diabetes mellitus, coronary heart disease, cerebrovascular accident, and cancer (15). Reduced insulin sensitivity (i.e. insulin resistance) is present in mid-childhood and has been indirectly demonstrated in late infancy in SGA children (16-18). These observations add support to the notion that events in fetal life have led to programmed insulin resistance. Inconsistency in the site(s) of insulin resistance in SGA have been reported but they appear to include both peripheral and hepatic insulin resistance (19-22).

The reduction in insulin sensitivity is magnified by fat mass accumulation, and several studies have demonstrated that greater catch-up growth is associated with disease attributable to insulin resistance. In lower birth weight individuals, early childhood acceleration in weight gain that is sustained throughout adolescence characterizes those that go on to develop type 2 diabetes mellitus (23). A similar pattern was observed with reduced birth weight in adults who developed coronary heart disease (24). Interestingly, by 4 y of age, SGA children already have a noticeable reduction in muscle mass with a smaller increase in fat mass compared with normal birth weight children (25). Even when adjusting for fat mass and sex, SGA children have reduced leptin levels (26).

Although fasting lipids are higher in SGA children, they remain in the normal range (25,27-29). It is not until early adult life that overt dyslipidemia is evident with the metabolic syndrome seen in $2.3 \%$ of SGA compared with $0.4 \%$ of normal birth weight young adults (30).

Most, but not all studies have found that premature pubarche occurred more frequently in SGA girls characterized by elevated dehydroepiandrosterone levels and a higher risk of both ovarian hyperandrogenism and polycystic ovarian syndrome (PCOS) (31-34). As insulin resistance is a recognized association with both SGA and PCOS it is not surprising the two have been linked. Indeed insulin resistance is believed to be a prime early factor in the pathogenesis of PCOS (35).

Prematurely born children. Conceptually, there are similarities between SGA and premature children. SGA infants suffer from an adverse fetal environment during the last trimester of pregnancy whereas very premature infants (defined as birth weight $\leq 1500 \mathrm{~g}$ ) suffer from an adverse neonatal environment in a neonatal intensive care unit during the first 3 mo of life, a time biologically equivalent to the third trimester. Therefore it is not surprising that there are similarities in the linear growth, body composition and metabolic changes during childhood observed in term SGA and very prematurely born children. Approximately $80 \%$ of children in both groups exhibit acceleration in growth to achieve a normal height by 6 mo of age. Those born very premature are approximately 0.7 SD shorter than their parents right across the height range, indicating that prematurely born children are short for their genetic height potential $(36,37)$. Final height data from recent studies reveal conflicting results that collectively indicate that very premature children reach a height that falls short of genetic height potential by $6-8 \mathrm{~cm}(0.5-0.7 \mathrm{SD}$ shorter) (38-40). Remarkably few studies have attempted to define which prenatal or neonatal events have a long-term influence on growth in those born prematurely. Very premature infants who received early neonatal dexamethasone therapy to prevent chronic lung disease were shorter than untreated children at 7-10 y of age (41). However, the mechanism in which neonatal dexamethasone therapy led to long-term poor growth is unclear.

During childhood, children born very premature exhibited low plasma IGF-I and IGFBP-3 levels compared with height and weight matched control children (42). This is in contrast with term SGA children who demonstrated elevated IGF-I levels (13). Both SGA and premature groups have unexplained elevated plasma IGF-II values $(36,43)$. Serum IGF-II levels have been shown to be associated with fat mass in normal children, with higher levels seen in obese children $(44,45)$. It has been proposed that the elevated plasma IGF-II levels observed in premature children play a role in the development of later obesity during adult life (44).

While detailed metabolic changes have yet to be fully characterized in very premature children, reduced insulin sensitivity has been demonstrated and is of a similar magnitude to term SGA children (46). Low protein intake in the first 3 mo of life occurred in the premature group, which was proposed as the trigger to epigenetic modification of genes involved in glucose regulation (47). Other factors such as prenatal or neonatal glucocorticoid exposure and illness in the neonatal period were not associated with insulin sensitivity (46).

The paucity of childhood or adolescent body composition data of those born very prematurely suggest similarities with SGA children and adolescents with increased fat mass, particularly abdominal fat by 19 y of age $(48,49)$. However, similar to SGA cohorts, more rapid catch-up growth was associated with greater reduction in insulin sensitivity (47). Consistent with reduced insulin sensitivity, limited data also suggests that those born prematurely are at increased of premature pubarche accounting for $24 \%$ of cases presenting for specialist evaluation (33).

IVF children. Low birth weight occurs more commonly in singleton IVF infants $(50,51)$. There is a 2.6 -fold increased risk of low birth weight in term IVF infants, with a greater risk of prematurity such that $0.4 \%$ of all very low birth weight infants are conceived by IVF. There are limited conflicting data regarding the auxological and hormonal characteristics of children born following IVF. Kai et al. (52) found that IVF children were the same height with the same serum IGF-I levels as control children. However, the study was limited by a low participation rate, with over half the IVF children being premature, SGA, or twin, which are all conditions that constrain growth. We have found that IVF children are approximately $4 \mathrm{~cm}$ taller $(0.5 \mathrm{SD})$ when corrected for parents' heights compared with normally conceived children (submitted for publication). IVF children had higher IGF-I to IGFBP3 
ratios, higher plasma IGF-II and more favorable lipid profile than matched control children. Further studies are needed to determine whether differences in IVF practice lead to differences in phenotype or biochemical indices.

\section{EPIGENETICS CONCEPTS}

The lack of a clear mechanism that leads to sustained programmed changes in growth and metabolism following an adverse fetal or early neonatal environment led Waterland and Garza (53) to coin the term "metabolic imprinting" to focus research in the field on identifying underlying mechanisms that include nutritional regulation of gene expression. It has long been known that the phenotype of an individual is not exclusively determined by genotype. Waddington (54) introduced the term epigenetics in the late 1950s that today is interpreted as changes in gene function that occur without a changes in gene sequence. Inherent in this concept is that conformational change in chromatin can repress transcription activation of gene expression. Chromatin conformation is closely linked to methylation, which occurs on cytosine residues at $\mathrm{CpG}$ dinucleotides. Although about $80 \%$ of $\mathrm{CpG}$ in the genome are methylated, there are "islands" of $\mathrm{CpG}$, usually within gene promoters, that remain unmethylated. However, during development some of these $\mathrm{CpG}$ islands can become methylated with consequent silencing of the associated gene (55-57). The state of CpG methylation probably regulates accessibility of the transcription machinery to regions of DNA, with methylated $\mathrm{CpGs}$ restricting transcription and unmethylated $\mathrm{CpG}$ allowing the gene to be expressed (58). The effects of cytosine methylation are mediated through numerous histone modifications such as acetylation and methylation, which cause chromatin remodeling and subsequent gene silencing as summarized in Figure 1. Possible roles for DNA methylation include maintenance of chromosomal stability and the silencing of imprinted genes, the inactive $\mathrm{X}$ chromosome and also of transposons.

In mammalian development, there are two main periods of epigenetic modification. During gametogenesis, genome-wide demethylation occurs followed by remethylation before fertilization. Early embryogenesis is then characterized by a second genome-wide demethylation event (59). Methylation is reestablished early in embryonic life following implantation. These postfertilization demethylation and remethylation phases are likely to play a role in the removal of acquired epigenetic modifications, particularly those acquired during gametogenesis $(60,61)$. Importantly, a subgroup of genes that carry parental methylation imprints appear to escape the second wave of demethylation.

Imprinted genes that undergo genomic or parental imprinting are among the most well-understood examples of epigenetic transcriptional modification. A subset of approximately 80 genes in humans display mono-allelic expression, i.e. expression only occurs from a single parental allele (62). Genomic imprinting-induced silencing of one parental allele results in mono-allelic expression from either the paternal or maternal copy of a gene. The imprint control regions for genomic imprinting usually contain a differentially methylated
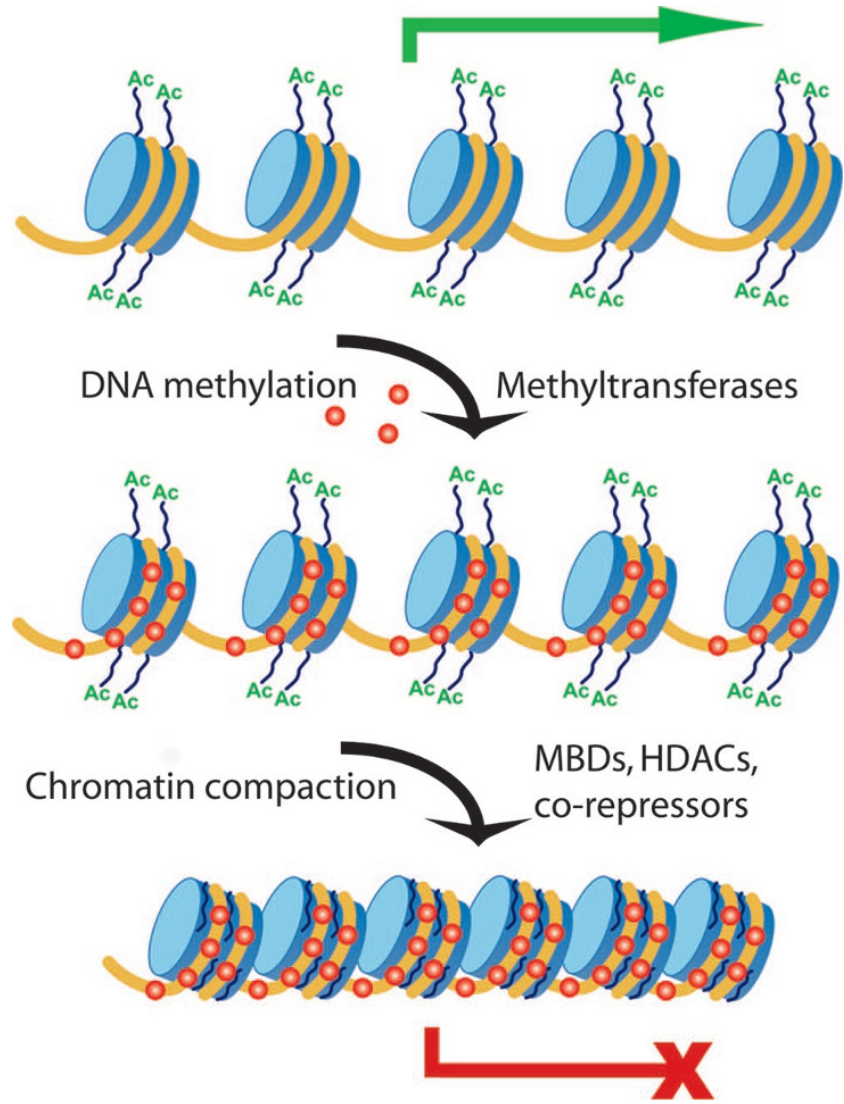

Figure 1. Epigenetic modifications in gene silencing. A series of epigenetic modifications transforms transcriptionally active regions of DNA (top) into inactive compact chromatin (bottom). DNA methylation, executed by methyltransferases, allows recruitment of methyl-binding domain proteins (MBD), which then recruit histone deacetylases (HDAC, transcriptional co-repressors and other chromatin modifying enzymes). Transcriptionally active chromatin is associated with acetylated histones, whereas inactive chromatin has methylated DNA and de-acetylated histones, as well as other histone modifications that are not shown.

$\mathrm{CpG}$ island in which one parental allele is methylated and the other unmethylated. A list of the phenotypes of known and likely imprinted genes are listed in Table 1. A regularly updated website of all known imprinted genes in humans and animals is available at www.otago.ac.nz/igc.

Table 1. Human phenotypes associated with imprinted genes or parent-of-origin effects

Phenotype Location

\begin{tabular}{|c|c|}
\hline \multicolumn{2}{|l|}{ Syndromes involving imprinted genes } \\
\hline Beckwith-Wiedemann syndrome & $11 \mathrm{p} 15$ \\
\hline Prader-Willi syndrome & $15 q 11-q 12$ \\
\hline Angelman syndrome & $15 \mathrm{q} 11-\mathrm{q} 12$ \\
\hline Silver-Russell syndrome & 7p11-p13, 7q31-qter,11p15 \\
\hline Transient neonatal diabetes mellitus & $6 \mathrm{q} 24$ \\
\hline $\begin{array}{l}\text { PHP1b, Albright hereditary osteodystrophy, } \\
\text { McCune-Albright syndrome }\end{array}$ & $20 \mathrm{q} 13$ \\
\hline \multicolumn{2}{|c|}{ Syndromes that probably involve imprinted genes } \\
\hline Familial nonchromaffin paraganglioma & $11 \mathrm{q} 13$ \\
\hline Maternal UPD 14 syndrome & 14 \\
\hline Paternal UPD 14 syndrome & 14 \\
\hline Maternal UPD 2 syndrome & 2 \\
\hline Maternal UPD 16 syndrome & 16 \\
\hline Turner syndrome phenotypes & $\mathrm{X}$ \\
\hline
\end{tabular}




\section{EPIGENETICS AND EARLY LIFE PERIODS}

The peri-conceptual period. The concept that early nutrition or disruptive environmental influences might alter imprinting regulation is supported by extensive experimental data in rodents and observational studies in humans. Early nutrition can influence DNA methylation because mammalian one carbon metabolism, which is the source of all methyl groups for all biologic methylation reactions, is very dependent upon dietary methyl donors and cofactors (63). Several studies have begun to test the hypothesis that altered nutrition, as reflected in various culture medium during IVF, can alter methylation and expression of imprinted genes ( 64-66). Mouse embryos cultured in Whitten's media showed loss in methylation of the $H 19$ differentially methylated region (DMR) that was not seen in embryos culture in KSOM with amino acids (66). In addition, mouse embryos cultured in the presence of FCS had reduced viability, reduced body weight, decreased expression of $H 19$ and $I G F 2$, and increased methylation of the $H 19$ imprinting control region when compared with controls (67). Collectively, these studies show that epigenetic alterations in the early embryo can be maintained to later stages of development.

Similarly, recent studies have shown that the process of IVF with in vitro manipulation in humans can produce imprinting changes like those seen in mice. An increased incidence of BWS, an overgrowth disorder associated with altered imprinting of genes including IGF2, has been reported in IVF offspring ( $68-70)$. In the only case control study performed, a 9-fold increased risk of BWS after IVF was found (71). Similarly, AS, a neurocognitive disorder, can be associated with loss of methylation in imprinted gene clusters and has been reported following IVF ( 72, 73). These epidemiologic associations between IVF and BWS or AS are strengthened by additional observations linking IVF to epigenetic changes. In 15 of 21 cases of BWS or AS following IVF, an epigenetic defect due to loss of methylation of the maternal allele was found ( $68-70,72,73)$. In a meta-analysis, 23 of the 24 cases of BWS following IVF were found to be due to hypomethylation of KvDMRI (74). In AS cases, hypomethylation of SNRPN was found to be the cause of the disorder (72). BWS or AS due to imprinting defects are the result of dramatic changes in DNA methylation. It is conceivable that less marked changes in DNA methylation will result in a far more subtle phenotype that could initially manifest as differences in growth patterns.

Recently epigenetic mutations have been identified that are common causes of Silver Russell Syndrome, a disorder characterized by very low birth weight, limb asymmetry and poor early childhood growth ( 75-77). Epigenetic modification of H19DMR and KvDMR1 occur in approximately 35\% of children with clinical features of Silver Russell syndrome (75-77). Hypomethylation of H19 DMR1 that will lead to reduced IGF2 expression accounts for $20 \%$ of Silver Russell syndrome cases (77). Interestingly, Silver Russell syndrome and BWS may be regarded as two disorders caused by opposite (epi)genetic disturbances of the same chromosomal region displaying opposite clinical pictures.
Late gestation and early neonatal periods. Data from animal models have indicated that the epigenetic lability of imprinted genes is not limited to the early embryonic period. There are a growing number of studies that have examined the impact of late fetal and early postnatal nutrition or adverse environmental factors on methylation of both imprinted and nonimprinted genes, which has led to altered gene expression. The strongest evidence in humans linking altered fetal nutrition with programmed changes in metabolism comes from the Dutch famine study, which found that young adult subjects conceived during the famine demonstrated higher 2-h plasma glucose values following an oral glucose load than controls born before or conceived after the famine (78).

Late gestation uteroplacental artery ligation leads to intrauterine growth restriction (IUGR) and reduction in renal mass in rats. At $21 \mathrm{~d}$ of age, increased p53 expression and promoter hypomethylation in the kidney was found (79). Hypomethylation of the gene for $\mathrm{p} 53$, an apoptosis regulator in the kidney, is the proposed mechanism for late fetal renal apoptosis and loss of glomeruli in animals with IUGR (79). MacLennan et al. (80) have more intricately explored the relationship between one carbon metabolism and DNA methylation in the rodent late gestation uteroplacental artery ligation model. An abnormality in one carbon metabolism was found in the liver, suggesting that increased hepatic levels of s-adenosylhomocysteine reduced availability of methyl donors that led to genome wide DNA hypomethylation (80).

Treatment of mice with a global inhibitor of DNA methylation at postnatal d 11 and 14 led to dramatic alteration in allelic expression of $I G F 2$ (81). The effect of more subtle changes in postnatal nutrition on imprinted gene expression were examined by Waterland and Garza (82). Rats were suckled in divergent litter sizes. Smaller litter sizes led to overnutrition, whereas large litter size led to undernutrition. Immediately after weaning and in adulthood, pancreatic beta cells from the smaller litter animals displayed impaired glucose stimulated insulin secretion. DNA microarray analysis revealed altered expression of two imprinted genes (insulin2 and neuronatin) and eight methylated genes found within pancreatic islet cells. These findings suggest that early postnatal diet has led to altered gene methylation and expression, reflecting enhanced epigenetic lability to early nutritional influences.

\section{EPIGENETICS AND THE PLACENTA}

The placenta contains all known imprinted genes and it has been suggested that they play roles in total placental growth as well as differential growth of specific cell types and activities of certain transporters ( 83-85). Overall, therefore, they may play a significant part in determining placental nutrient delivery. It has been deduced from studies with knockout mice that the maternally expressed genes appear to abrogate placental growth whereas the paternally expressed genes enhance placental growth. There is evidence that imprinted genes may also regulate an organic cation transporter and components of the system A amino acid transporter ( 83-87). In particular, the placental labyrinth-specific PO transcript of the paternally 
imprinted Igf2 gene in mice has been suggested as a powerful regulator of placental growth that can alter placental efficiency and placental nutrient permeability (88).

It has now been demonstrated also that nonimprinted genes key to placental growth and function as well as mechanisms of pregnancy maintenance and parturition are under epigenetic control. For instance the activity of a gene for a critical enzyme in prostaglandin biosynthesis (prostaglandin $\mathrm{H}$ synthase-2) can be modified by alteration of histone acetylation status and DNA methylation status in human placental explants (89). This effect was tissue-specific with effects on amnion but not adjacent chorio-decidua. Moreover, similar alterations result in massive changes in IL- $1 \beta$ output by human placental explants (90). These inflammatory mediator substances have substantial effects on uteroplacental hemodynamics and are critical in mechanisms of labour both at term and preterm. The regulatory mechanisms extend back in pregnancy to at least the time of implantation since recent studies have demonstrated clearly that the implantation process is regulated epigenetically (91).

Presently, there are no direct data linking placental epigenetic changes to changes in and regulation of fetal phenotype at birth or later in life. We believe that such linkages are not only possible but highly likely. It is known that knockouts of key genes in mice can result in abnormal placentation and subsequently altered growth and development (e.g. growth restricted fetuses) that can also be fatal. We hypothesize that similar effects occur with abnormal epigenetic regulation of critical genes in the placenta. Testing of this hypothesis will require initially experiments in which key genes (e.g. DNA methyltransferases) are modified in a uterine-specific (preferably placental-specific) and gestational age-specific manner. Thereafter, similar experiments with epigenetically altered critical genes can determine specific regulatory pathways.

\section{DIETARY FOLATE AND DNA METHYLATION}

Folate and/or methyl group dietary studies provide the most compelling data for the interaction of nutrients with DNA methylation, because these dietary elements are directly involved in one carbon metabolism. The sole metabolic function of all co-enzymatic forms of folate is to transfer one carbon units for reaction such as methylation. Folate deficiency affects DNA stability through two principal pathways: DNA hypomethylation and DNA synthesis and repair (92). In humans, the major source of methyl groups in humans comes from methionine and to a lesser extent choline. Pregnancy, fetal, and early neonatal life are periods in which there is a high demand for folate and supplementation is usually given to preterm infants once full oral feeding is established. Serial plasma folate measurements in 140 preterm infants fell progressively to very low levels by the second to third week of life, at which time full oral feeding was achieved and folate supplementation was introduced (93). Those not supplemented continued to have low serum folate levels. Therefore, premature infants are at risk of a period of up to several weeks of folate deficiency that could conceivably lead to DNA hypomethylation.
Effects of dietary methyl donors (methionine and choline) and folate on DNA methylation have been reported in rodent and human studies. For example, rats fed a diet deficient in methionine and choline exhibited a change from normal DNA methylation to global DNA hypomethylation that included specific gene hypomethylation $(94,95)$. A folate-deficient diet introduced to healthy rats led to DNA hypomethylation in the brain (96). Further support for the important role of methyl donor sufficiency in changing DNA methylation long term was identified in a study of methyl supplementation in two strains of pregnant mice. Supplementation led to enhanced DNA methylation of an LTR element with a mutant agouti gene creating a leaner phenotype of the offspring (97).

The strongest argument linking folate deficiency with metabolic gene hypomethylation was established in rat offspring whose mothers were fed a low-protein diet during pregnancy (98). DNA methylation of the glucocorticoid receptor was lower and gene expression higher than offspring from controlfed animals (98). Interestingly, the addition of folic acid to the low protein diet prevented this change in methylation and expression from occurring. This observation may have relevance to the insulin resistance seen in children born SGA or prematurely. Activation of the glucocorticoid receptor leads to glucocorticoid induced insulin resistance in liver and in skeletal muscle $(99,100)$.

Data from animal studies indicate that folate or methyl group deficiency during late fetal life or early postnatal life produces stable long-term total DNA and specific gene hypomethylation. Conversely, studies in adult rats and humans suggest that folate- or methyl group-deficient diets lead to DNA hypomethylation that reverses with resumption of a normal diet $(94,95,101)$. Collectively these observations suggest that there is an unexplained ontogenic window in which nutritional deficiency leads to persistent DNA hypomethylation during fetal and early neonatal life that does not exist in adults.

\section{CANDIDATE GENES}

There are a number of epigenetically modifiable gene candidates that could play a role in programmed changes in growth and insulin sensitivity in IVF, SGA, and prematurely born children. These include imprinted genes, since imprinting is known to be disrupted in some IVF children, but also nonimprinted genes involved in growth and metabolism.

Candidate genes that might explain the taller stature and elevated IGF-II levels seen in our IVF children include the growth genes IGF2 and CDKNIC (p57KIP2), which are controlled by methylation at H19 DMR and KvDMR1, respectively. Conversely, changes in methylation at the putatively polymorphically imprinted IGF2 receptor gene locus could lead to decreased IGF-II activity and small size at birth due to increased numbers of the sink IGF-II receptor $(102,103)$. Similarly overexpression of RASGRF1, which regulates postnatal growth and is known to be imprinted in rodents, could explain the taller stature and higher IGF-I levels in IVF children. Conversely, underexpression of RASGRF1, which is 
known to be imprinted in rodents, could explain poor childhood growth in SGA and prematurely born children (104).

Other candidates include leptin, in which reduced levels play a critical role in the development of the metabolic syndrome in rats (insulin resistance, hypertension and dyslipidemia) (105). Newborn SGA rats treated with a short course of leptin displayed a normal adult phenotype without any biochemical evidence of metabolic syndrome (105). Therefore, there appears to be a critical window in early life in which under nutrition causing aberrant methylation of LEP could lead to persistent insulin resistance and development of adult obesity and hypertension. This is yet another plausible mechanism whereby children born prematurely could develop insulin resistance.

GRB10 is an imprinted gene that acts to inhibit insulin and IGF-I receptor signalling (106). It has been established that GRB10 is not the cause of Russell Silver syndrome, a discrete syndromal cause of SGA children (107). GRB10 hypomethylation during the fetal or early neonatal periods could cause insulin resistance, poor growth, and abnormalities in the GH/ IGF-I axis as observed in SGA and premature children.

\section{SUMMARY}

There are persistent alterations in growth and metabolism in SGA, very premature, and IVF children. These changes, which appear to be programmed from early life environmental exposure, must involve altered cellular function and probably altered gene expression. However, the trigger(s) and mechanism(s) that lead to these programmed changes have yet to be elucidated in humans. There is compelling evidence from animal studies that environmental factors such as altered nutrition lead to epigenetic changes and altered gene expression, however, it is unclear whether these changes lead to metabolic disease. Future studies in animal models will better define the long-term disease risks of epigenetic changes following specific nutritional or environmental manipulation. Although animal models of SGA or IVF cannot be easily extrapolated to humans and animal models of prematurity do not yet exist, using the available data we hypothesize that an adverse embryonic, fetal, or neonatal environment is responsible for epigenetic modification leading to the growth and metabolic changes observed in later childhood. Further studies are needed to examine candidate genes for methylation changes and in particular establish methylation patterns in different tissues. Accessing target tissues remains one of the major limitations in human studies. Limited current data support epigenetic change as a mechanism behind the observed phenotypic changes in IVF, SGA, and prematurely born cohorts. Epigenetics is likely to become a major focus of attention for developmental biologists in establishing mechanisms that link adverse early life events with later adult disease.

\section{REFERENCES}

1. Barker DJ 1990 The fetal and infant origins of adult disease. BMJ 301:1111

2. Barker DJ, Hales CN, Fall CH, Osmond C, Phipps K, Clark PM 1993 Type 2 (non-insulin-dependent) diabetes mellitus, hypertension and hyperlipidaemia (syndrome X): relation to reduced fetal growth. Diabetologia 36:62-67
3. Barker DJ, Osmond C, Law CM 1989 The intrauterine and early postnatal origins of cardiovascular disease and chronic bronchitis. J Epidemiol Community Health 43:237-240

4. Barker DJ, Winter PD, Osmond C, Margetts B, Simmonds SJ 1989 Weight in infancy and death from ischaemic heart disease. Lancet 2:577-580

5. Curhan GC, Willett WC, Rimm EB, Spiegelman D, Ascherio AL, Stampfer MJ 1996 Birth weight and adult hypertension, diabetes mellitus, and obesity in US men. Circulation 94:3246-3250

6. Boyko EJ 2000 Proportion of type 2 diabetes cases resulting from impaired fetal growth. Diabetes Care 23:1260-1264

7. Eriksson JG, Osmond C, Barker DJ 2003 Pathways of infant and childhood growth that lead to type 2 diabetes. Diabetes Care 26:3006-3010

8. Karlberg J, Albertsson-Wikland K 1995 Growth in full-term small-for-gestationalage infants: from birth to final height. Pediatr Res 38:733-739

9. Tenovuo A, Kero P, Piekkala P, Korvenranta H, Sillanpaa M, Erkkola R 1987 Growth of 519 small for gestational age infants during the first two years of life. Acta Paediatr Scand 76:636-646

10. Albertsson-Wikland K, Karlberg J 1994 Natural growth in children born small for gestational age with and without catch-up growth. Acta Paediatr Suppl 399:64-70

11. Leger J, Levy-Marchal C, Bloch J, Pinet A, Chevenne D, Porquet D, Collin D, Czernichow P 1997 Reduced final height and indications for insulin resistance in 20 year olds born small for gestational age: regional cohort study. BMJ 315:341-347

12. Boguszewski M, Rosberg S, Albertsson-Wikland K 1995 Spontaneous 24-hour growth hormone profiles in prepubertal small for gestational age children. J Clin Endocrinol Metab 80:2599-2606

13. Cutfield WS, Hofman PL, Vickers M, Breier B, Blum WF, Robinson EM 2002 IGFs and binding proteins in short children with intrauterine growth retardation. J Clin Endocrinol Metab 87:235-239

14. Ranke MB 2006 Sensitivity to IGF-I in short children born small for gestational age. J Endocrinol Invest 29:21-26

15. Facchini FS, Hua N, Abbasi F, Reaven GM 2001 Insulin resistance as a predictor of age-related diseases. J Clin Endocrinol Metab 86:3574-3578

16. Hofman PL, Cutfield WS, Robinson EM, Bergman RN, Menon RK, Sperling MA, Gluckman PD 1997 Insulin resistance in short children with intrauterine growth retardation. J Clin Endocrinol Metab 82:402-406

17. Soto N, Bazaes RA, Pena V, Salazar T, Avila A, Iniguez G, Ong KK, Dunger DB, Mericq MV 2003 Insulin sensitivity and secretion are related to catch-up growth in small-for-gestational-age infants at age 1 year: results from a prospective cohort. J Clin Endocrinol Metab 88:3645-3650

18. Arends NJ, Boonstra VH, Duivenvoorden HJ, Hofman PL, Cutfield WS, HokkenKoelega AC 2005 Reduced insulin sensitivity and the presence of cardiovascular risk factors in short prepubertal children born small for gestational age (SGA). Clin Endocrinol (Oxf) 62:44-50

19. Jensen CB, Storgaard H, Dela F, Holst JJ, Madsbad S, Vaag AA 2002 Early differential defects of insulin secretion and action in 19-year-old Caucasian men who had low birth weight. Diabetes 51:1271-1280

20. Stefan N, Weyer C, Levy-Marchal C, Stumvoll M, Knowler WC, Tataranni PA, Bogardus C, Pratley RE 2004 Endogenous glucose production, insulin sensitivity, and insulin secretion in normal glucose-tolerant Pima Indians with low birth weight. Metabolism 53:904-911

21. Ozanne SE, Jensen CB, Tingey KJ, Storgaard H, Madsbad S, Vaag AA 2005 Low birthweight is associated with specific changes in muscle insulin-signalling protein expression. Diabetologia 48:547-552

22. Jaquet D, Gaboriau A, Czernichow P, Levy-Marchal C 2000 Insulin resistance early in adulthood in subjects born with intrauterine growth retardation. J Clin Endocrinol Metab 85:1401-1406

23. Hypponen E, Power C, Smith GD 2003 Prenatal growth, BMI, and risk of type 2 diabetes by early midlife. Diabetes Care 26:2512-2517

24. Barker DJ, Osmond C, Forsen TJ, Kajantie E, Eriksson JG 2005 Trajectories of growth among children who have coronary events as adults. N Engl J Med 353:1802-1809

25. Ibanez L, Ong K, Dunger DB, de Zegher F 2006 Early development of adiposity and insulin resistance after catch-up weight gain in small-for-gestational-age children. J Clin Endocrinol Metab 91:2153-2158

26. Tenhola S, Halonen P, Jaaskelainen J, Voutilainen R 2005 Serum markers of GH and insulin action in 12-year-old children born small for gestational age. Eur J Endocrinol 152:335-340

27. Bazaes RA, Alegria A, Pittaluga E, Avila A, Iniguez G, Mericq V 2004 Determinants of insulin sensitivity and secretion in very-low-birth-weight children. J Clin Endocrinol Metab 89:1267-1272

28. Veening MA, van Weissenbruch MM, Delemarre-van de Waal HA 2004 Sequelae of syndrome $\mathrm{X}$ in children born small for gestational age. Horm Res 61:103-107

29. Arends NJ, Boonstra VH, Duivenvoorden HJ, Hofman PL, Cutfield WS, HokkenKoelega AC 2005 Reduced insulin sensitivity and the presence of cardiovascular risk factors in short prepubertal children born small for gestational age (SGA). Clin Endocrinol (Oxf) 62:44-50

30. Jaquet D, Czernichow P 2003 Born small for gestational age: increased risk of type 2 diabetes, hypertension and hyperlipidaemia in adulthood. Horm Res 59:131-137

31. Ibanez L, Potau N, Ferrer A, Rodriguez-Hierro F, Marcos MV, De Zegher F 2002 Anovulation in eumenorrheic, nonobese adolescent girls born small for gestational age: insulin sensitization induces ovulation, increases lean body mass, and reduces abdominal fat excess, dyslipidemia, and subclinical hyperandrogenism. J Clin Endocrinol Metab 87:5702-5705 
32. Boonstra VH, Mulder PG, de Jong FH, Hokken-Koelega AC 2004 Serum dehydroepiandrosterone sulfate levels and pubarche in short children born small for gestational age before and during growth hormone treatment. J Clin Endocrinol Metab 89:712-717

33. Neville KA, Walker JL 2005 Precocious pubarche is associated with SGA, prematurity, weight gain, and obesity. Arch Dis Child 90:258-261

34. Ibanez L, Ong K, Valls C, Marcos MV, Dunger DB, de Zegher F 2006 Metformin treatment to prevent early puberty in girls with precocious pubarche. J Clin Endocrinol Metab 91:2888-2891

35. Dunaif A 1997 Insulin resistance and the polycystic ovary syndrome: mechanism and implications for pathogenesis. Endocr Rev 18:774-800

36. Cutfield WS, Regan FA, Jackson WE, Jefferies CA, Robinson EM, Harris M, Hofman PL 2004 The endocrine consequences for very low birth weight premature infants. Growth Horm IGF Res 14:S130-S135

37. Finken MJ, Dekker FW, de Zegher F, Wit JM. Dutch Project on Preterm, Small-for-Gestational-Age-19 Collaborative Study Group 2006 Long-term height gain of prematurely born children with neonatal growth restraint: parallelism with the growth pattern of short children born small for gestational age. Pediatrics 118:640-643

38. Hack M, Schluchter M, Cartar L, Rahman M, Cuttler L, Borawski E 2003 Growth of very low birth weight infants to age 20 years. Pediatrics 112:e30-e38

39. Peralta-Carcelen M, Jackson DS, Goran MI, Royal SA, Mayo MS, Nelson KG 2000 Growth of adolescents who were born at extremely low birth weight without major disability. J Pediatr 136:633-640

40. Saigal S, Stoskopf BL, Streiner DL, Burrows E 2001 Physical growth and current health status of infants who were of extremely low birth weight and controls at adolescence. Pediatrics 108:407-415

41. Yeh TF, Lin YJ, Lin HC, Huang CC, Hsieh WS, Lin CH, Tsai CH 2004 Outcomes at school age after postnatal dexamethasone therapy for lung disease of prematurity. N Engl J Med 350:1304-1313

42. Cutfield W 2004 Short and sweet: the perinatal origins of typ2 diabetes mellitus. Pediatr Diabetes 5:113-116

43. Cutfield WS, Jackson WE, Jefferies C, Robinson EM, Breier BH, Richards GE, Hofman PL 2003 Reduced insulin sensitivity during growth hormone therapy for short children born small for gestational age. J Pediatr 142:113-116

44. Juul A, Dalgaard P, Blum WF, Bang P, Hall K, Michaelsen KF, Muller J, Skakkebaek NE 1995 Serum levels of insulin-like growth factor (IGF)-binding protein-3 (IGFBP-3) in healthy infants, children, and adolescents: the relation to IGF-I, IGF-II, IGFBP-1, IGFBP-2, age, sex, body mass index, and pubertal maturation. J Clin Endocrinol Metab 80:2534-2542

45. Ong KK, Dunger DB 2002 Perinatal growth failure: the road to obesity, insulin resistance and cardiovascular disease in adults. Best Pract Res Clin Endocrinol Metab 16:191-207

46. Hofman PL, Regan F, Jackson WE, Jefferies C, Knight DB, Robinson EM, Cutfield WS 2004 Premature birth and later insulin resistance. N Engl J Med 351:2179 2186

47. Regan FM, Cutfield WS, Jefferies C, Robinson E, Hofman PL 2006 The impact of early nutrition in premature infants on later childhood insulin sensitivity and growth. Pediatrics 118:1943-1949

48. Euser AM, Finken MJ, Keijzer-Veen MG, Hille ET, Wit JM, Dekker FW The Dutch POPS-19 Collaborative Study Group 2005 Associations between prenatal and infancy weight gain and BMI, fat mass, and fat distribution in young adulthood: a prospective cohort study in males and females born very preterm. Am J Clin Nutr 81:480-487

49. Doyle LW, Faber B, Callanan C, Ford GW, Davis NM 2004 Extremely low birth weight and body size in early adulthood. Arch Dis Child 89:347-350

50. Wennerholm UB, Bergh C 2004 Outcome of IVF pregnancies. Fetal Matern Med Rev 15:27-57

51. Schieve LA, Meikle SF, Ferre C, Peterson HB, Jeng G, Wilcox LS 2002 Low and very low birth weight in infants conceived with use of assisted reproductive technology. N Engl J Med 346:731-737

52. Kai CM, Main KM, Andersen AN, Loft A, Chellakooty M, Skakkebaek NE, Juul A 2006 Serum insulin-like growth factor (IGF-I) and growth in children born after assisted reproduction. J Clin Endocrinol Metab 91:4352-4360

53. Waterland RA, Garza C 1999 Potential mechanisms of metabolic imprinting that lead to chronic disease. Am J Clin Nutr 69:179-197

54. Waddington C 1957 The Study of the Genes. Allen and Unwin, London

55. Larsen F, Gundersen G, Lopez R, Prydz H 1992 CpG islands as gene markers in the human genome. Genomics 13:1095-1107

56. Bird AP 1986 CpG-rich islands and the function of DNA methylation. Nature 321:209-213

57. Wolf SF, Jolly DJ, Lunnen KD, Friedmann T, Migeon BR 1984 Methylation of the hypoxanthine phosphoribosyltransferase locus on the human X chromosome: implications for X-chromosome inactivation. Proc Natl Acad Sci U S A 81:28062810

58. Saxonov S, Berg P, Brutlag DL 2006 A genome-wide analysis of CpG dinucleotides in the human genome distinguishes two distinct classes of promoters. Proc Natl Acad Sci U S A 103:1412-1417

59. Santos F, Hendrich B, Reik W, Dean W 2002 Dynamic reprogramming of DNA methylation in the early mouse embryo. Dev Biol 241:172-182

60. Pickard B, Dean W, Engemann S, Bergmann K, Fuermann M, Jung M, Reis A, Allen N, Reik W, Walter J 2001 Epigenetic targeting in the mouse zygote marks DNA for later methylation: a mechanism for maternal effects in development. Mech Dev 103:35-47

61. Reik W, Dean W, Walter J 2001 Epigenetic reprogramming in mammalian development. Science 293:1089-1093
62. Morison IM, Ramsay JP, Spencer HG 2005 A census of mammalian imprinting. Trends Genet 21:457-465

63. Van den Veyver IB 2002 Genetic effects of methylation diets. Annu Rev Nutr 22:255-282

64. Niemann H, Wrenzycki C 2000 Alterations of expression of developmentally important genes in preimplantation bovine embryos by in vitro culture conditions: implications for subsequent development. Theriogenology 53:21-34

65. Eppig JJ, O'Brien MJ 1998 Comparison of preimplantation developmental competence after mouse oocyte growth and development in vitro and in vivo. Theriogenology 49:415-422

66. Doherty AS, Mann MR, Tremblay KD, Bartolomei MS, Schultz RM 2000 Differential effects of culture on imprinted H19 expression in the preimplantation mouse embryo. Biol Reprod 62:1526-1535

67. Khosla S, Dean W, Brown D, Reik W, Feil R 2001 Culture of preimplantation mouse embryos affects fetal development and the expression of imprinted genes. Biol Reprod 64:918-926

68. DeBaun MR, Niemitz EL, Feinberg AP 2003 Association of in vitro fertilization with Beckwith-Wiedemann syndrome and epigenetic alterations of LIT1 and H19. Am J Hum Genet 72:156-160

69. Maher ER, Brueton LA, Bowdin SC, Luharia A, Cooper W, Cole TR, Macdonald F, Sampson JR, Barratt CL, Reik W, Hawkins MM 2003 Beckwith-Wiedemann syndrome and assisted reproduction technology (ART). J Med Genet 40:62-64

70. Gicquel C, Gaston V, Mandelbaum J, Siffroi JP, Flahault A, Le Bouc Y 2003 In vitro fertilization may increase the risk of Beckwith-Wiedemann syndrome related to the abnormal imprinting of the KCN1OT gene. Am J Hum Genet 72:1338-1341

71. Halliday J, Oke K, Breheny S, Algar EJ, Amor D 2004 Beckwith-Wiedemann syndrome and IVF: a case-control study. Am J Hum Genet 75:526-528

72. Cox GF, Burger J, Lip V, Mau UA, Sperling K, Wu BL, Horsthemke B 2002 Intracytoplasmic sperm injection may increase the risk of imprinting defects. Am J Hum Genet 71:162-164

73. Orstavik KH, Eiklid K, van der Hagen CB, Spetalen S, Kierulf K, Skjeldal O, Buiting K 2003 Another case of imprinting defect in a girl with Angelman syndrome who was conceived by intracytoplasmic semen injection. Am J Hum Genet 72:218-219

74. Maher ER 2005 Imprinting and assisted reproductive technology. Hum Mol Genet 14:R133-R138

75. Gicquel C, Rossignol S, Cabrol S, Houang M, Steunou V, Barbu V, Danton F, Thibaud N, Le Merrer M, Burglen L, Bertrand AM, Netchine I, Le Bouc Y 2005 Epimutation of the telomeric imprinting center region on chromosome $11 \mathrm{p} 15$ in Silver-Russell syndrome. Nat Genet 37:1003-1007

76. Eggermann T, Schonherr N, Meyer E, Obermann C, Mavany M, Eggermann K, Ranke MB, Wollmann HA 2006 Epigenetic mutations in 11 p15 in SilverRussell syndrome are restricted to the telomeric imprinting domain. J Med Genet 43:615-616

77. Schonherr N, Meyer E, Eggermann K, Ranke MB, Wollmann HA, Eggermann T 2006 (Epi)mutations in 11p15 significantly contribute to Silver-Russell syndrome: but are they generally involved in growth retardation? Eur J Med Genet 49:414-418

78. Roseboom TJ, van der Meulen JH, Ravelli AC, Osmond C, Barker DJ, Bleker OP 2001 Effects of prenatal exposure to the Dutch famine on adult disease in later life: an overview. Mol Cell Endocrinol 185:93-98

79. Pham TD, MacLennan NK, Chiu CT, Laksana GS, Hsu JL, Lane RH 2003 Uteroplacental insufficiency increases apoptosis and alters p53 gene methylation in the full-term IUGR rat kidney. Am J Physiol Regul Integr Comp Physiol 285:R962-R970

80. MacLennan NK, James SJ, Melnyk S, Piroozi A, Jernigan S, Hsu JL, Janke SM, Pham TD, Lane RH 2004 Uteroplacental insufficiency alters DNA methylation, one-carbon metabolism, and histone acetylation in IUGR rats. Physiol Genomics $18: 43-50$

81. Hu JF, Nguyen PH, Pham NV, Vu TH, Hoffman AR 1997 Modulation of Igf2 genomic imprinting in mice induced by 5-azacytidine, an inhibitor of DNA methylation. Mol Endocrinol 11:1891-1898

82. Waterland RA, Garza C 2002 Early postnatal nutrition determines adult pancreatic glucose-responsive insulin secretion and islet gene expression in rats. [Erratum appears in J Nutr 2002 May;132(5):1055.] J Nutr 132:357-364

83. Reik W, Constancia M, Fowden A, Anderson N, Dean W, Ferguson-Smith A, Tycko B, Sibley C 2003 Regulation of supply and demand for maternal nutrients in mammals by imprinted genes. J Physiol 547:35-44

84. Myatt L 2006 Placental adaptive responses and fetal programming. J Physiol 572:25-30

85. Fowden AL, Ward JW, Wooding FP, Forhead AJ, Constancia M 2006 Programming placental nutrient transport capacity. J Physiol 572:5-15

86. Mizuno Y, Sotomaru Y, Katsuzawa Y, Kono T, Meguro M, Oshimura M, Kawai J, Tomaru Y, Kiyosawa H, Nikaido I, Amanuma H, Hayashizaki Y, Okazaki Y 2002 Asb4, Ata3, and Dcn are novel imprinted genes identified by high-throughput screening using RIKEN cDNA microarray. Biochem Biophys Res Commun 290:1499-1505

87. Dao D, Frank D, Qian N, O'Keefe D, Vosatka RJ, Walsh CP, Tycko B 1998 IMPT1, an imprinted gene similar to polyspecific transporter and multi-drug resistance genes. Hum Mol Genet 7:597-608

88. Constancia M, Hemberger M, Hughes J, Dean W, Ferguson-Smith A, Fundele R, Stewart F, Kelsey G, Fowden A, Sibley C, Reik W 2002 Placental-specific IGF-II is a major modulator of placental and fetal growth. Nature 417:945-948

89. Mitchell MD 2006 Unique suppression of prostaglandin H synthase-2 expression by inhibition of histone deacetylation, specifically in human amnion but not adjacent choriodecidua. Mol Biol Cell 17:549-553 
90. Sato TA, Mitchell MD 2006 Contact paracrine inhibitory networks within human gestational tissues. Am J Obstet Gynecol 195:1396-1397

91. Rahnama F, Shafiei F, Gluckman PD, Mitchell MD, Lobie PE 2006 Epigenetic regulation of human trophoblastic cell migration and invasion. Endocrinology 147:5275-5283

92. Duthie SJ, Narayanan S, Brand GM, Pirie L, Grant G 2002 Impact of folate deficiency on DNA stability. J Nutr 132:2444S-2449S

93. Fuller NJ, Bates CJ, Cole TJ, Lucas A 1992 Plasma folate levels in preterm infants, with and without a $1 \mathrm{mg}$ daily folate supplement. Eur J Pediatr 151:48-50

94. Wilson MJ, Shivapurkar N, Poirier LA 1984 Hypomethylation of hepatic nuclear DNA in rats fed with a carcinogenic methyl-deficient diet. Biochem J 218:987-990

95. Bhave MR, Wilson MJ, Poirier LA $1988 \mathrm{c}-\mathrm{H}-$ ras and c-K-ras gene hypomethylation in the livers and hepatomas of rats fed methyl-deficient, amino acid-defined diets. Carcinogenesis 9:343-348

96. Kim YI, Pogribny IP, Basnakian AG, Miller JW, Selhub J, James SJ, Mason JB 1997 Folate deficiency in rats induces DNA strand breaks and hypomethylation within the p53 tumor suppressor gene. Am J Clin Nutr 65:46-52

97. Cooney CA, Dave AA, Wolff GL 2002 Maternal methyl supplements in mice affect epigenetic variation and DNA methylation of offspring. J Nutr 132:2393S-2400S

98. Lillycrop KA, Phillips ES, Jackson AA, Hanson MA, Burdge GC 2005 Dietary protein restriction of pregnant rats induces and folic acid supplementation prevents epigenetic modification of hepatic gene expression in the offspring. J Nutr 135:1382-1386

99. Liu Y, Nakagawa Y, Wang Y, Sakurai R, Tripathi PV, Lutfy K, Friedman TC 2005 Increased glucocorticoid receptor and 11 beta\}-hydroxysteroid dehydrogenase type 1 expression in hepatocytes may contribute to the phenotype of type 2 diabetes in $\mathrm{db} / \mathrm{db}$ mice. Diabetes 54:32-40
100. Ruzzin J, Wagman AS, Jensen J 2005 Glucocorticoid induced insulin resistance in skeletal muscles: defects in insulin signalling and the effects of selective glycogen synthase kinase-3 inhibitor. Diabetologia 48:2119-2130

101. Shelnutt KP, Kauwell GP, Gregory JF3rd, Maneval DR, Quinlivan EP, Theriaque DW, Henderson GN, Bailey LB 2004 Methylenetetrahydrofolate reductase $677 \mathrm{C}->\mathrm{T}$ polymorphism affects DNA methylation in response to controlled folate intake in young women. J Nutr Biochem 15:554-560

102. McCann JA, Xu YQ, Frechette R, Guazzarotti L, Polychronakos C 2004 The insulin-like growth factor-II receptor gene is associated with type 1 diabetes: evidence of a maternal effect. J Clin Endocrinol Metab 89:5700-5706

103. Braidotti G, Baubec T, Pauler F, Seidl C, Smrzka O, Stricker S, Yotova I, Barlow DP 2004 The air noncoding RNA: an imprinted cis-silencing transcript. Cold Spring Harb Symp Quant Biol 69:55-66

104. Itier JM, Tremp GL, Leonard JF, Multon MC, Ret G, Schweighoffer F, Tocque B, Bluet-Pajot MT, Cormier V, Dautry F 1998 Imprinted gene in postnatal growth role. Nature 393:125-126

105. Vickers MH, Gluckman PD, Coveny AH, Hofman PL, Cutfield WS, Gertler A, Breier BH, Harris M 2005 Neonatal leptin treatment reverses developmental programming. Endocrinology 146:4211-4216

106. Miyoshi N, Kuroiwa Y, Kohda T, Shitara H, Yonekawa H, Kawabe T, Hasegawa H, Barton SC, Surani MA, Kaneko-Ishino T, Ishino F 1998 Identification of the Meg1/Grb10 imprinted gene on mouse proximal chromosome 11, a candidate for the Silver-Russell syndrome gene. Proc Natl Acad Sci U S A 95:1102-1107

107. Hitchins MP, Monk D, Bell GM, Ali Z, Preece MA, Stanier P, Moore GE 2001 Maternal repression of the human GRB10 gene in the developing central nervous system; evaluation of the role for GRB10 in Silver-Russell syndrome. Eur J Hum Genet 9:82-90 